Instructions/Template for Preparing Manuscript for Jendela Nursing Journal

\title{
Edukasi Range Of Motion Aktif Kaki dengan Audiovisual pada Penderita Diabetes Melitus Tipe II: Literature Review
}

\author{
Arinda Putri Hapsari ${ }^{1}$, Putrono ${ }^{1}$, Nina Indriyawati ${ }^{1}$ \\ ${ }^{1}$ Sarjana Terapan Keperawatan, Poltekkes Kemenkes Semarang, Indonesia \\ Corresponding Author: arkajsh4869@gmail.com
}

\begin{abstract}
Background: The number of death cause type II diabetic and the low of knowledge level in pyhsical activity is still high.

Purpose: This literature review discusses about the usage of audiovisual as media for education to increase the level of type II diabetic accusative's knowledge and skill in active lower ROM.

Methods: This research used 9 articles from over 96 international and national journals published between 2015-2019, five databases were used to facilitate the literature research (Pubmed, Elsevier, Google Scholar, dan SINTA). Inclusion and exclusion criteria for the literature search were applied and PRISMA guidelines followed. The inclusion criteria of studies using audiovisual, type II diabetic, and active lower ROM. The exclusion criteria of this research are research that used media except audiovisual. Results: The result from this literature review is from 9 articles show that audiovisual is a good media for education especially education to increase the level of Type II diabetic accusative's knowledge and skill in active lower ROM.
\end{abstract}

Conclusion: Audiovisual can be used as media for education to increase the level of type II diabetic accusative's knowledge and skill in lower active ROM.

\section{Keywords:}

Lower Active ROM, Audiovisual, Type II Diabetic Mellitus

\section{LATAR BELAKANG}

Komunikasi sebagai metode dasar dalam manusia menjalin hubungan sosial. Maraknya berbagai macam bentuk komunikasi merubah cara manusia saling berkoneksi, belajar dan mencari informasi (Scott, 2020). Penggunaan smartphone sudah menjadi suatu kebutuhan yang tidak dapat ditinggalkan. Melalui fitur yang didapat dari smartphone, para pengguna dapat lebih mudah mengakses berbagai macam informasi. Salah satunya audiovisual yang memudahkan pengguna untuk membuat dan membagikan konten ke platform online mereka, seperti You Tube (Noel, 2018). Audiovisual menjadi media yang sesuai untuk pemberian edukasi. Dengan melihat fenomena saat ini, dalam pemberian edukasi diperlukan media yang tidak menyita banyak waktu, efektif, dan bisa dipelajari sewaktu-waktu. Media audiovisual mencakup kriteria tersebut (Ernayanti, 2019).

Didasari pada teori bahwa penderita DM tipe II harus mendapatkan edukasi tentang DM dan melakukan aktivitas fisik, salah satunya melakukan ROM aktif pada kaki, maka 
diperlukan media yang bisa menyampaikan informasi yang dapat diterima oleh penerima informasi secara baik dan benar. Penderita DM tipe II sebagai target sasaran dari edukasi ROM aktif kaki untuk meningkatkan pengetahuan dan kemampuan tersebut perlu pemberian informasi mengenai ROM aktif kaki pada penderita DM tipe II (Yulfa, 2018).

Penelitian tentang hubungan tingkat pengetahuan pasien DM terhadap melakukan aktivitas olah raga, memberikan hasil bahwa persentase tingkat pengetahuan pasien DM dalam melakukan olah raga yang termasuk dalam kategori rendah masih tinggi, yaitu 78,6\% (Fahlepie, 2012). Hal tersebut menunjukkan diperlukan adanya pendidikan kesehatan untuk meningkatkan pengetahuan pasien DM melakukan olah raga.

Pemberian edukasi menjadi salah satu poin yang bisa mengubah perilaku dalam melakukan aktivitas olah raga(Jayanti, Falah, \& Dasong, 2019). Program edukasi yang sudah diterapkan di beberapa rumah sakit dan diteliti oleh beberapa peneliti adalah program edukasi dengan metode kelompok, leaflet dan booklet, serta dengan metode demonstrasi (Apriani et al., 2012; Farudin, 2011).

Namun, media yang digunakan ketika melakukan pendidikan kesehatan baiknya menggunakan media yang menarik dan mudah dipahami oleh sasaran. Audio visual menjadi jalan keluarnya dikarenakan media ini melibatkan semua indera pembelajaran sehingga sasaran bisa menerima informasi yang disampaikan dengan baik (Jayanti et al., 2019). Berdasarkan penelitian sebelumnya yaitu tentang keefektifan pendidikan kesehatan SADARI antara leaflet dengan media audiovisual menunjukkan media audiovisual lebih efektif dalam penyampaian informasi kepada sasaran $(\mathrm{p}=0.003 \leq 0.05)$ (Alini \& Indrawati, 2018).

\section{METODE}

Penelitian ini menggunakan desain penelitian kajian literature. Strategi pencarian artikel melalui database jurnal penelitian terindeks nasional dan internasional seperti Pubmed, Elsevier, Google Scholar, dan SINTA. Batas maksimal publikasi artikel penelitian dalam kurun waktu 5 tahun terakhir. Kata kunci yang digunakan dalam pencarian artikel penelitian yaitu diabetes melitus tipe II, range of motion aktif kaki, health education, audiovisual, type II diabetes melitus, dan lower active range of motion. Kriteria inklusi pada penelitian ini yaitu artikel penelitian terpublikasi dan terindeks di jurnal nasional maupun internasional periode tahun 2015-2019, jenis artikel penelitian asli, diakses secara gratis, dapat diakses dalam bentuk teks lengkap, media yang digunakan dalam bentuk audiovisual, menjelaskan tentang DM tipe II dan range of motion (ROM) aktif kaki. Kriteria eksklusi pada penelitian ini yaitu jurnal yang tidak terindeks, media yang digunakan selain audiovisual misalnya leaflet, peer group, poster, dan lain-lain. Artikel penelitian yang didapatkan sebanyak 9 artikel, dianalisis dan disintesis dalam format tabel berisi penulis, tahun, metodologi, hasil dan rekomendasi. 


\section{Bagan 1. Proses Seleksi Artikel Penelitian}

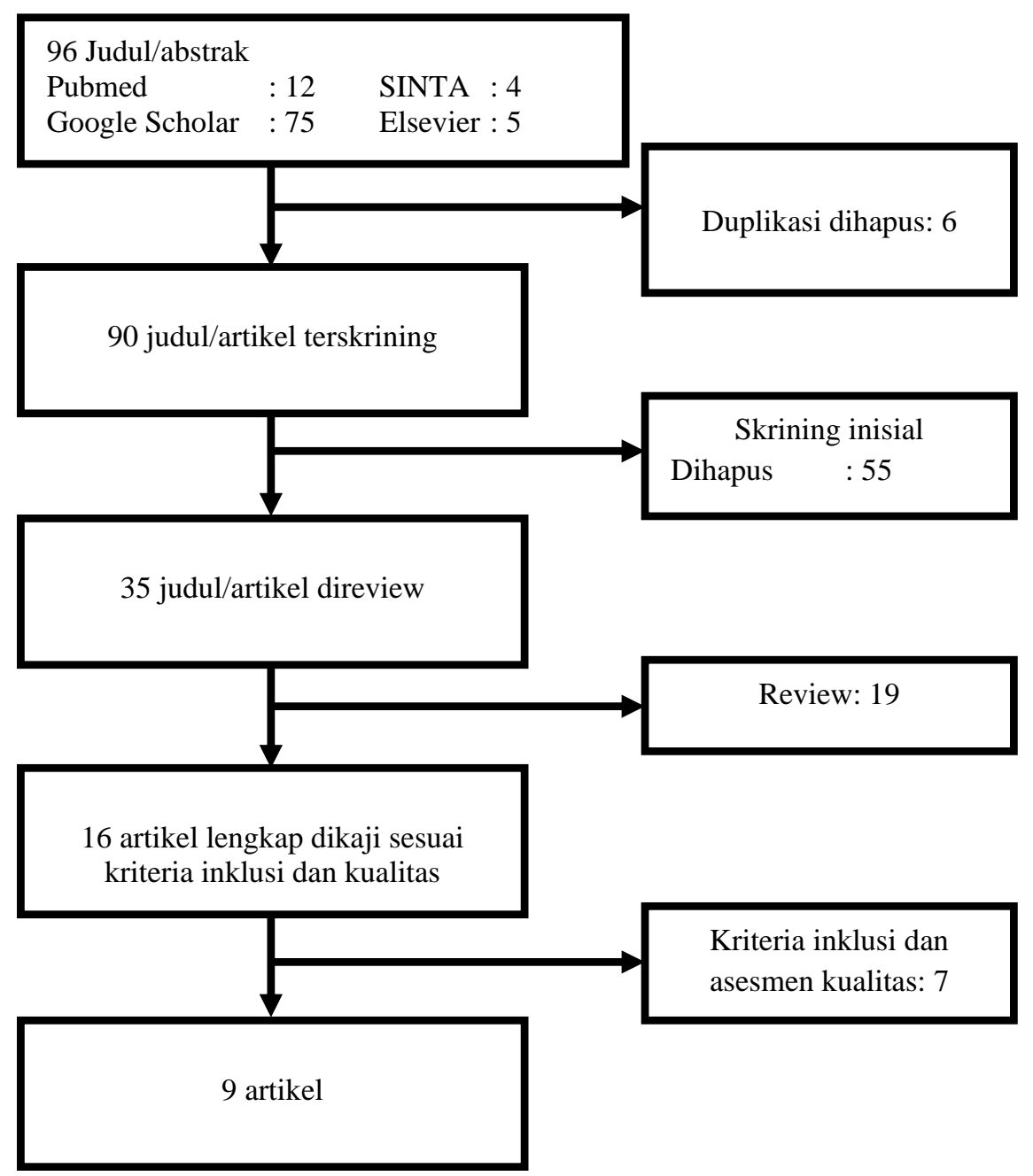




\section{HASIL}

Tabel 1. Ringkasan artikel penggunaan media audiovisual sebagai media pendidikan kesehatan ROM aktif kaki pada penderita DM tipe II tahun 2015-2019 (n=9)

\begin{tabular}{|c|c|c|c|c|c|c|}
\hline No & Penulis & Tahun & Judul & Desain & Sampel & Hasil \\
\hline 1. & $\begin{array}{l}\text { Okatiranti, Tita } \\
\text { Puspitaningrum, } \\
\text { Anggi Saputra }\end{array}$ & 2018 & $\begin{array}{l}\text { Impact of } \\
\text { Health } \\
\text { Education of } \\
\text { Foot Exercise: } \\
\text { On Knowledge } \\
\text { and Skill of } \\
\text { Type } \\
\text { Diabetes } \\
\text { Mellitus } \\
\text { Patients At } \\
\text { Elderly } \\
\text { Community } \\
\text { Health } \\
\text { Post(Posbindu), } \\
\text { Indonesia }\end{array}$ & $\begin{array}{l}\text { Pre- } \\
\text { eksperimental } \\
\text { dengan } \\
\text { desain pre } \\
\text { dan post test } \\
\text { dalam satu } \\
\text { kelompok } \\
\text { (one group } \\
\text { pre-post-test } \\
\text { design) tanpa } \\
\text { kontrol }\end{array}$ & $\begin{array}{c}46 \\
\text { responden }\end{array}$ & $\begin{array}{l}\text { Pada penelitian ini } \\
\text { menunjukkan adanya } \\
\text { pengaruh pemberian } \\
\text { pendidikan kesehatan } \\
\text { dengan audiovisual } \\
\text { pada penderita DM tipe } \\
\text { II. Terjadi peningkatan } \\
\text { pengetahuan } \\
\text { kemampuan } \\
\text { signifikan. yang }\end{array}$ \\
\hline 2. & $\begin{array}{l}\text { Nur Roddiyah } \\
\text { Furry } \\
\text { Anggraini, } \\
\text { Tanto } \\
\text { Hariyanto, } \\
\text { Warsono }\end{array}$ & 2018 & $\begin{array}{l}\text { Perbedaan } \\
\text { Tingkat } \\
\text { Pengetahuan } \\
\text { Tentang } \\
\text { Diabetes } \\
\text { Mellitus (DM) } \\
\text { Tipe II } \\
\text { Sebelum dan } \\
\text { Sesudah } \\
\text { Diberikan } \\
\text { Edukasi dengan } \\
\text { Media Audio } \\
\text { Visual pada } \\
\text { Penderita } \\
\text { Diabetes } \\
\text { Mellitus Tipe II } \\
\text { Di Dusun } \\
\text { Sentong Desa } \\
\text { Karangduren } \\
\text { Kecamatan } \\
\text { Pakisaji } \\
\text { Kabupaten } \\
\text { Malang }\end{array}$ & $\begin{array}{l}\text { Quasi } \\
\text { eksperimen } \\
\text { dengan one } \\
\text { group pre } \\
\text { post test } \\
\text { design }\end{array}$ & $\begin{array}{l}20 \\
\text { responden }\end{array}$ & $\begin{array}{l}\text { Terdapat perbedaan } \\
\text { tingkat pengetahuan } \\
\text { setelah } \\
\text { pendidikan kesehatan } \\
\text { menggunakan } \\
\text { audiovisual. Meskipun } \\
\text { tingkat pengetahuan } \\
\text { sebagian responden } \\
\text { masih kurang. Namun, } \\
\text { terdapat perbedaan } \\
\text { sebelum dan sesudah } \\
\text { diberikan pendidikan } \\
\text { kesehatan dengan } \\
\text { audiovisual }\end{array}$ \\
\hline 3. & $\begin{array}{ll}\text { Yulfa } & \text { Intan } \\
\text { Lukita, } & \text { Nur } \\
\text { Widayati, } & \\
\text { Wantiyah } & \end{array}$ & 2018 & $\begin{array}{l}\text { Pengaruh } \\
\text { Range of } \\
\text { Motion (ROM) } \\
\text { Aktif Kaki } \\
\text { terhadap Risiko } \\
\text { terjadinya } \\
\text { Ulkus Kaki } \\
\text { Diabetik pada } \\
\text { Pasien Diabetes }\end{array}$ & $\begin{array}{l}\text { Quasi } \\
\text { eksperimen } \\
\text { dengan pre } \\
\text { dan post test } \\
\text { dengan } \\
\text { kontrol }\end{array}$ & $\begin{array}{c}30 \\
\text { responden }\end{array}$ & $\begin{array}{l}\text { Dalam penelitian ini, } \\
\text { menunjukkan bahwa } \\
\text { ROM aktif kaki } \\
\text { membuktikan dapat } \\
\text { mengurangi resiko } \\
\text { terjadinya ulkus kaki } \\
\text { diabetik. }\end{array}$ \\
\hline
\end{tabular}


Mellitus Tipe

2 di Desa

Kaliwining

Kabupaten

Jember

4. Alfrida Jayanti, 2019 Fakhriatul

Falah, Saenab

Dasong

\section{Pengaruh}

Pendidikan

Kesehatan
Audiovisual

Terhadap

Peningkatan

Pengetahuan

Pasien Diabetes

Mellitus

Diruang

Perawatan

RSUD Labuang

Baji Makassar

5. Graceistin

Ruben, Julia

villy Rottie,

Michael Y.

Karundeng$$
2016
$$

Pengaruh

Senam

Kaki

Diabetes

Terhadap

Perubahan

6. Aria Wahyuni, 2016

Nina Arisfa

Dengan Metode

Kadar Gula

Darah pada

Pasien Diabetes

Melitus Tipe 2

di Wilayah

Kerja

Puskesmas

Enemawira

Quasi

Experimen

dengan

pendekatan

Non-

Equivalent

Control

Group

Pra

eksperimental

dengan one group pretest post test design

Senam Kaki

Diabetik

Efektif

Meningkatkan

Ankle Brachial

Quasi

eksperimen

one-group

pre-test

post-test.

Index Pasien

Diabetes

Melitus Tipe 2
14 Pada penelitian ini, responden pendidikan kesehatan dengan audiovisual memberikan pengaruh terhadap tingkat pengetahuan penderita DM. Media audiovisual memberikan informasi yang jelas dan kreatif.

56 orang Dalam penelitian ini, aktivitas kaki dapat menurunkan kadar gula dalam darah penderita DM. Terjadi penurunanan kadar gula dalam darah setelah dilakukan senam kaki.

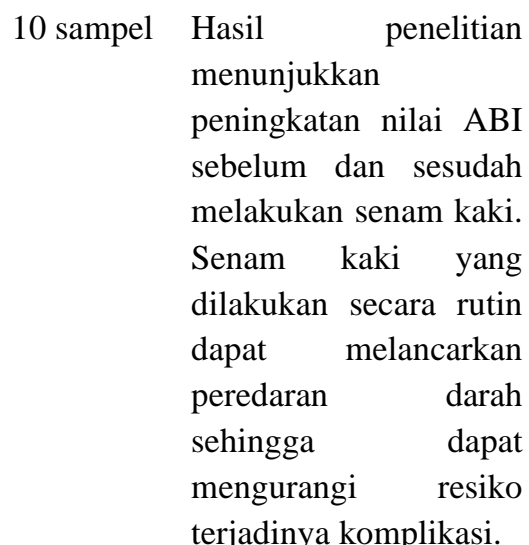




\begin{tabular}{|c|c|c|c|c|c|c|}
\hline \multirow[t]{9}{*}{7.} & \multirow{9}{*}{$\begin{array}{l}\text { Inartry } \\
\text { Mangiwa } \\
\text { Mario E. Katuk } \\
\text { Lando } \\
\text { Sumarauw }\end{array}$} & \multirow[t]{9}{*}{2017} & \multirow{2}{*}{$\begin{array}{ll}\text { Pengaruh } & \\
\text { Senam } & \text { Kaki }\end{array}$} & Eksperimen & \multirow[t]{9}{*}{30 orang } & \multirow{8}{*}{$\begin{array}{l}\text { Senam kaki diabetes } \\
\text { hanya menggunakan } \\
\text { koran dan kursi. } \\
\text { Dengan melakukan } \\
\text { kegiatan tersebut dapat } \\
\text { meningkatkan nilai } \\
\text { Ankle Brachial Index } \\
\text { menjadi normal. }\end{array}$} \\
\hline & & & & semu (quasi & & \\
\hline & & & Diabetes & experiment) & & \\
\hline & & & \multirow{6}{*}{$\begin{array}{l}\text { Terhadap Nilai } \\
\text { Ankle Brachial } \\
\text { Index pada } \\
\text { Pasien Diabetes } \\
\text { Melitus Tipe II } \\
\text { di Rumah Sakit } \\
\text { Pacaran Kasih } \\
\text { Gmim Manado }\end{array}$} & pre- and & & \\
\hline & & & & post-test & & \\
\hline & & & & without & & \\
\hline & & & & control & & \\
\hline & & & & & & \\
\hline & & & & & & \\
\hline \multirow[t]{12}{*}{8.} & \multirow{12}{*}{$\begin{array}{l}\text { Yuyun } \\
\text { Christyanni, } \\
\text { Novi Mery Kala } \\
\text { Aheng, } \\
\text { Yongwan } \\
\text { Nyamin }\end{array}$} & \multirow[t]{12}{*}{2019} & Edukasi Senam & \multirow{2}{*}{$\begin{array}{l}\text { Quasy } \\
\text { experiment }\end{array}$} & \multirow[t]{12}{*}{30 orang } & \multirow{12}{*}{$\begin{array}{l}\text { Pemberian pendidikan } \\
\text { kesehatan senam kaki } \\
\text { dengan audiovisual } \\
\text { memberikan pengaruh } \\
\text { terhadap keterampilan } \\
\text { dalam melakukan } \\
\text { senam kaki pada } \\
\text { penderita } \\
\text { Terdapat perbedaan } \\
\text { yang signifikan setelah } \\
\text { pemberian edukasi. }\end{array}$} \\
\hline & & & Kakiterhadap & & & \\
\hline & & & Kemampuan & one group & & \\
\hline & & & Melakukan & pre- $\quad$ and & & \\
\hline & & & Senam Kaki & post-test & & \\
\hline & & & Pada Penderita & design. & & \\
\hline & & & Diabetes & & & \\
\hline & & & Melitus Tipe 2 & & & \\
\hline & & & di Puskesmas & & & \\
\hline & & & Kereng & & & \\
\hline & & & Bangkirai & & & \\
\hline & & & Palangka Raya & & & \\
\hline \multirow[t]{8}{*}{9.} & \multirow{8}{*}{$\begin{array}{l}\text { Sandra } \\
\text { Pebrianti, } \\
\text { Andry Tahta } \\
\text { Pramudya, } \\
\text { Yatimah Pratiwi }\end{array}$} & \multirow[t]{8}{*}{2018} & Latihan & \multirow{8}{*}{$\begin{array}{l}\text { Literature } \\
\text { review }\end{array}$} & 10 artikel, & \multirow{8}{*}{$\begin{array}{l}\text { Dari literature review } \\
\text { yang menganalisis } 10 \\
\text { artikel, menunjukkan } \\
\text { bahwa ROM kaki dapat } \\
\text { melancarkan peredaran } \\
\text { darah sehingga nutrisi } \\
\text { dapat tertuju ke area } \\
\text { luka, sehingga dapat } \\
\text { mempercepat proses } \\
\text { penyembuhan luka. }\end{array}$} \\
\hline & & & Ektremitas & & Google & \\
\hline & & & Bawah pada & & Scholar, & \\
\hline & & & Pasien & & Proquest & \\
\hline & & & Denganulkus & & $\begin{array}{c}\text { dan } \\
\text { Pubmed }\end{array}$ & \\
\hline & & & Kaki Diabetik: & & periode & \\
\hline & & & Literature & & publikasi & \\
\hline & & & Review & & $\begin{array}{l}2006- \\
2017\end{array}$ & \\
\hline
\end{tabular}

Dalam mencari jurnal nasional maupun internasional, penyusunan literature review menggunakan situs Pubmed, Elsevier, Google Scholar, dan SINTA. Jurnal yang didapatkan dari search engine berjumlah 96. Setelah dilakukan proses filtrasi dan analisa, didapatkan 9 artikel. Fokus utama dalam pengambilan jurnal adalah edukasi ROM aktif kaki dengan media audiovisual terhadap peningkatan pengetahuan penderita DM tipe II. Dengan kriteria inklusi penyakit DM tipe II, ROM aktif kaki serta media edukasi audiovisual. Untuk kriteria eksklusinya yaitu penelitian yang menggunakan media lain selain audiovisual dalam proses pemberian edukasi. Terdapat 4 jurnal mengenai edukasi audiovisual dengan DM tipe II serta 5 jurnal mengenai ROM aktif kaki dengan DM tipe II. Kisaran sampel yang digunakan dalam penelitian berkisar 10 sampai 56 responden. Metode yang digunakan pada sebagian besar penelitian menggunakan quasy experimental study.

Penggunaan audiovisual sebagai media edukasi memiliki nilai tambahan tersendiri. Dengan pemberian informasi berupa video atau gambar dan suara, membuat informasi yang diterima semakin lebih jelas dan membuat penerima informasi menjadi tidak cepat 
bosan. Dengan jelasnya informasi yang diterima dapat meningkatkan pengetahuan seseorang menjadi lebih paham. Dan dengan menggunakan indera penglihatan serta pendengaran menjadikan informasi yang diserap menjadi lebih jelas.

Keunggulan menggunakan audiovisual sebagai media edukasi adalah banyak masyarakat yang sudah mengenal mengenai media audiovisual, pada media ini semua panca indra digunakan, dalam segi pemahaman lebih mudah untuk dimengerti, adanya kolaborasi antara suara dan gambar sehingga membuat tampilan materi lebih menarik, serta media audiovisual merupakan media yang dapat digunakan untuk diskusi dan dapat diputar ulang sewaktu waktu.

Selain memiliki kelebihan, media audiovisual juga memiliki kelemahan antara lain biaya pembuatan yang kurang terjangkau atau lebih mahal, membutuhkan suatu alat yang canggih dalam proses pembuatan, membutuhkan persiapan serta konsep yang benar benar matang, memerlukan keterampilan dalam pengoperasian dan hanya terjadi komunikasi satu arah jika menggunakan media audiovisual ini.

\section{PEMBAHASAN}

Pemberian pendidikan kesehatan dan latihan fisik range of motion aktif kaki dapat mencegah kejadian komplikasi yang dikarenakan DM tipe II. Berdasarkan kajian literature dari 9 artikel penelitian yang sudah dianalisa, menunjukkan bahwa pendidikan kesehatan ROM aktif kaki dengan media audiovisual lebih efektif diberikan dibanding dengan metode pendidikan kesehatan yang menggunakan media selain audio visual.

Pengetahuan merupakan hasil interpretasi indera manusia terhadap suatu informasi atau objek. Ada beberapa faktor yang mempengaruhi pengetahuan semua orang yaitu usia, pendidikan, pekerjaan dan pengalaman (Wulan Dari et al., 2018). Dengan pengetahuan, penderita DM dapat meningkatkan kualitas hidupnya secara mandiri. Dari penelitian yang dilakukan Anggraini (2018) didapat satu faktor yang meningkatkan tingkat pengetahuan responden yaitu recall atau metode mengingat kembali apa yang sudah diberikan. Namun dalam memberian edukasi perlu media yang tepat.

Edukasi dengan audiovisual lebih efektif diberikan kepada sasaran dikarenakan media tersebut melibatkan semua alat indra. Sehingga penerimaan informasi lebih dipahami, dimengerti, dan diingat (Alfrida, 2019). Dilihat dari hasil jawaban responden, dapat dikaji bahwa responden lebih dapat memahami tentang materi yang diberikan seperti pengertian, faktor yang mempengaruhi, komplikasi dan pencegahan dari DM. Dan setelah diberikan perlakuan berupa edukasi dengan audiovisual pada kelompok intervensi didapatkan nilai mean rank 3.00. Hal ini sangat berbeda dengan nilai mean rank sebelum diberikan perlakuan yaitu 0.00 , hal tersebut membuktikan bahwa ada pengaruh setelah pemberian perlakuan.

Penelitian yang telah dilakukan oleh Alfrida selaras dengan penelitian yang dilakukan Okatiranti (2018), dengan jumlah responden sebanyak 46 orang lanjut usia. Hasilnya menunjukkan bahwa sebelum pemberian edukasi, responden dengan pengetahuan yang bagus berkisar $19.6 \%$, menengah $58.7 \%$, dan pengetahuan yang kurang sebesar 8.7 $\%$.Dan untuk kemampuan dalam melakukan latihan kaki, $8.7 \%$ untuk responden yang sudah bisa dan $91.3 \%$ untuk sisanya.Namun, setelah diberikan edukasi dengan media audiovisual, terjadi peningkatan jumlah responden dengan pengetahuan yang bagus 
(23.9\%), menengah (63\%), dan pengetahuan yang masih kurang menurun (13\%).Dan untuk kemampuan dalam melakukan latihan kaki, lebih dari setengah responden bisa mendemostrasikan dengan baik latihan kaki (54.3\%).Berdasarkan penelitian ini, responden yang berumur lebih dari 55 tahun memiliki tingkat pengetahuan yang baik dibuktikan dengan latihan kaki yang dilakukan.

Latihan fisik berupa senam kaki atau range of motion (ROM) aktif kaki merupakan jenis latihan aerobik yang dianjurkan untuk penderita DM. Latihan tersebut membutuhkan oksigen, dimana oksigen dapat melancarkan aliran darah, memperkuat otot dan mencegah deformitas yang meningkatkan potensi terjadinya ulkus diabetik.

Latihan fisik berupa ROM aktif kaki pada 20 responden (Yulfa, 2018), didapatkan hasil terjadi penurunan nilai resiko ulkus diabetik yaitu 2.267.Prinsip latihan yang dilaksanakan dalam penelitian ini dilakukan sebanyak 2 kali dalam 13 hari pertama dan 1 kali di hari ke 14. Dengan dilakukannya latihan ROM aktif kaki dapat mengaktifkan kontraksi otot kaki yang menyebabkan terjadinya kompresi sehingga kerja pembuluh darah lebih lancar. Hal ini sangat membantu penderita DM tipe II dimana kerja pengiriman oksigen dan nutrisi ke sel atau saraf atau pembuluh darah yang lebih kecil menurun yang dikarenakan aliran darah yang kurang lancar.

Dari penelitian yang dilakukan Okatiranti (2018), pada 46 responden di Komunitas Lansia Bandung dengan 9.6\% memiliki pengetahuan yang bagus, $58.7 \%$ pengetahuan cukup, dan $21.7 \%$ memiliki pengetahuan yang kurang. Setelah diberikan edukasi berupa foot exercise dengan media audiovisual terjadi perubahan atau peningkatan persentase, kelompok responden dengan pengetahuan bagus naik menjadi $23.9 \%$, pengetahuan cukup menjadi $63 \%$, dan kelompok responden dengan pengetahuan kurang naik menjadi $13 \%$.

Banyak manfaat yang didapat dari pemberian edukasi menggunakan audiovisual sebagai medianya. Tampilan yang lebih menarik dan dapat diputar ulang sewaktuwaktu. Namun, kekurangan dari media ini yakni komunikasi satu arah. Penerima informasi tidak bisa berdiskusi jika ada sesuatu yang ingin ditanyakan (Desrianti, 2011).

Edukasi yang adekuat akan meningkatkan kemampuan penderita untuk melakukan selfcare sehingga dapat mengontrol kadar gula dalam darah secara optimal dan resiko komplikasi menjadi lebih rendah. Dari hal tersebut membuktikan bahwa ada pengaruh antara pemberian simulasi foot exercise dan kemampuan penderita DM tipe II. Melalui kajian literature ini diharapkan memberikan pandangan dalam pemberian edukasi yang dilakukan oleh tenaga kesehatan dalam segala sektor.

Dengan berbagai macam tingkat pengetahuan dan pemahaman setiap individu dalam menerima informasi, diperlukan media yang dapat dipelajari sewaktu-waktu, media yang yang mudah diterima dan tidak membosankan.Dengan tingkat pengetahuan yang baik, maka penderita DM tipe II dapat meningkatkan kualitas hidup yang baik pula.Oleh karena itu audiovisual sangat diperlukan sebagai media dalam memberikan edukasi ROM aktif kaki.Melalui studi literature ini, dapat disimpulkan bahwa media audiovisual dapat meningkatkan pengetahuan ROM aktif kaki pada penderita DM tipe II. 


\section{SIMPULAN}

Kesimpulan dari analisis artikel-artikel penelitian yang telah dilakukan adalah penggunaan media audiovisual sebagai media edukasi khususnya dalam memberikan edukasi range of motion (ROM) aktif kaki pada penderita DM tipe II dapat meningkatkan pemahaman dan pengetahuan penderita akan pentingnya ROM dan bagaimana cara mengaplikasikannya secara baik dan benar. Dengan media yang menarik dan dapat diulang sewaktu-waktu akan mempermudah dalam penerimaan informasi. Berdasarkan teori yang sudah ada, bahwa penderita DM tipe II disarankan untuk menerima edukasi tentang aktivitas fisik salah satunya berupa ROM aktif kaki untuk menghindari komplikasi. Dengan menggunakan media audiovisual sebagai media dalam memberikan edukasi akan meningkatkan pengetahuan dan pemahaman penderita DM tipe II.

\section{REFERENSI}

Alini \& Indrawati. (2018). Efektifitas Promosi Kesehatan Melalui Audio Visual dan Leaflet Tentang SADARI (Pemeriksaan Payudara Sendiri) Terhadap Peningkatan Pengatahuan Remaja Putri Tentang SADARI di SMAN $N 1$ Kampar. 2(2), 1-9.

Anggraini, Nur Roddiyah Furry, Tanto Hariyanto, \& Warsono. (2018). Perbedaan Tingkat Pengetahuan Tentang DIabetes MElitus (DM) Tipe II Sebelum dan Sesudah Diberikan Edukasi Dengan Media Audio Visual Pada Penderita Diabetes Melitus Tipe II di Dusun Sentong Desa Karangduren Kecamatan Pakisaji Kabupaten Malang. Nursing News. 3(1), 492-500.

Apriani, S., Raksanagara, A. S., Windani, C., Sari, M., Program, M., Keperawatan, M., .. Program, S. P. (2012). Pengaruh Program Edukasi Dengan Metode Kelompok Terhadap Perilaku Perawatan Diri Pasien Diabetes Melitus Tipe 2. (2008). Retrieved from http://ejournal.stikesborromeus.ac.id/file/jurnal 3.pdf

Jayanti, A., Falah, N. F., \& Dasong, H. S. (2019). Pengaruh Pendidikan Kesehatan Dengan Metode Audiovisual Terhadap Peningkatan Pengetahuan Pasien Diabetes Mellitus Diruang Perawatan RSUD Labuang Baji Makassar. 2(1), 1823.

Lukita, Y. I. (2018). Pengaruh Range Of Motion (ROM) Aktif Kaki Terhadap Risiko Terjadinya Ulkus Kaki Diabetik Pada Pasien Diabetes Melitus Tipe 2 Di Desa Kaliwining Kecamatan Rambipuji Kabupaten Jember. E-Jurnal Pustaka Kesehatan, 6(2), 58.

Mangiwa, Inartry, Mario E. Katuk, \& Lando Sumarauw. (2017). Pengaruh Senam Kaki Diabetes Terhadap Nilai ANkle Brachial Index Pada Pasien Diabetes Melitus Tipe II Di Rumah Sakit Pacaran Kasih GMIM Manado. E-Journal Keperawatan. 2(1)

Okatiranti, Puspitaningrum, T., \& Saputra, A. (2018). Impact of Health Education of Foot Exercise: on Knowledge And Skill Of Type II Diabetes Mellitus Patients at Elderly Community Health Post (POSBINDU), Indonesia. (138).

Ruben, Graceistin, Julia villy Rottie, \& Michael Y. Karundeng. (2016). Pengaruh Senam Kaki Diabetes Terhadap Perubahan Kadar Gula Darah Pada Pasien Diabetes Melitus Tipe II di Wilayah Kerja Puskesmas Enemawira. E-Journal Keperawatan. 4(1).

Wahyuni, Aria \& Nina Arisfa. (2016). Senam Kaki Diabetik Meningkatkan Ankle Brachial Index Pasien Diabetes Melitus Tipe 2. 9(i2), 155-164. 
http://dx.doi.org/10.22216/jit.2015.v9i2.231

Wulan Dari, N., Nurchayati, S., \& Hasanah, O. (2014). Pengaruh Pendidikan Kesehatan Senam Kaki Melalui Media Audio Visual Terhadap Pengetahuan Pelaksanaan Senam Kaki Pada Pasien Dm Tipe 2. Jom Psik, 1(2), 1-7. 